\title{
Designing Legal Language in Strengthening The Degree of Legal Certainty
}

\author{
Mohamad Sinal \\ State Polytechnic of Malang, Jl. Soekarno Hatta No. 9 Malang, East Java, Indonesia
}

\begin{abstract}
This work is aimed at visualizing the importance of legal language in guaranteeing legal certainty that may minimize as well as eliminate the differences of interpretation among of legal drafters, legislators, other legal officers in order to create justice for all. In practice, those differences root at three core problems: (i) inability of legal drafters or legislators in formulating rules into appropriate legal language; (ii) the weaknesses of legal officers interpreting the legal language; and (iii) the lack of knowledge of society in understanding the legal language. For that reason, this work will elaborate and discuss the way to design, to formulate and to function the norms and mechanism of legal language that can strengthen the degree of legal certainty. In this context, it emphasizes the importance of several core elements that can guarantee the legal certainty that are characteristics and standard guidance in utilizing the legal language. In detail, those characteristics can seen at its clarity and its consistency. At the end, this work will show the standard and steps in designing and formulating and using the legal language that may strengthen the degree of legal certainty, which in turn to create justice for all.
\end{abstract}

Keywords: legal language, legal certainty, the law, justice, legal elements

DOI: $10.7176 / J L P G / 81-11$

\section{Introduction}

Viewed from philosophy of science, legal science can be divided into two, dogmatic legal science and empirical legal science ${ }^{1}$. Both term in the research is called as normative and empirical legal sciences. Normative legal science is legal science that focuses to positive law. Normative legal science functioned (a) to describe the positive law, describe the content and structure of positive law, (b) to systematize the positive law, systematize the content and structure of positive law, (c) to interpret the positive law, interpret the contained meaning (d) to assess the positive law, assess the norm dimension in the rule, and (e) to analyze the positive law, analyze the rule of law and legal principles. Empirical legal science is the legal science that views the law as facts that can be observed and value free. The characters of empirical legal science such as; differentiates the facts to the norms, views the legal symptoms as purely empiric, views the legal symptoms as social facts, uses the empirical science methods, and view the legal science as something value free ${ }^{2}$.

Law contains rules, concepts, measures that were determined by the rulers or law makers to (a) be delivered to the community (b) be understood the meaning and (c) be obeyed ${ }^{3}$. Based on this statement, it can be stated that the law is created for societal interest. Because of that the legal rules should be understandable by society. The legal rules should not make society confuses, because if they confuse then they will harm the society, because the society should obey the law. Because of that the law will be used to regulate the societal behavior, then the legal norms writing or legal product that uses good and correct Indonesian language should be given serious attention. The goal is to make society understands well the content of the law.

Rules of law firstly aim at the concrete violations. The rules of law does not to perfect the human being, but for public order, to avoid them from to be the criminal victims or not to do crime ${ }^{4}$. In this case, the rules of law content aim at the physical attitude of human being. The rules of law give emphasis to the physical action. What people think is not the legal problems, if physically it does not violate the rules of law ${ }^{5}$.

Based on explanation above, it can be stated that law serves as the protector for human or societal interests. Law serves to divide rights and duties among person in the society. Beside that, law serves to divide authorities and regulate the way to solve legal problems and preserve the legal certainty ${ }^{6}$. Then, to communicate the legal functions to the legal users need language as the communication medium ${ }^{7}$. Because of that, to analyze, formulate, and answer the legal problems and to reconstruct an legal event clearly and precisely, it needs understanding and mastering the language sufficiently ${ }^{8}$.

The explanation signalizes that to compile and formulate the legal norms or legal products should consider the linguistic rules. Disobedience to the linguistic rules able to produce wrong meaning and multi interpretable. Because of that, the used language in the area of law should be avoided from ambiguity because ambiguity able to produce law uncertainty. Law uncertainty able to produce society that disobey to the law. Because of that, the serious review about the usage of Indonesian language in the national area of law need to be done. The use of Indonesian language in the laws and regulations, criminal codes (KUHP), or other regulations that were the legacy of the Dutch actually not suitable with the development of Indonesian language. The used language in the legislation of Dutch legacy was not Indonesian language, but old Malay language that was influenced by linguistic style and linguistic rule of the Dutch ${ }^{9}$. 
Based on above it can be stated that the creation of legal certainty for society or the legal users is very important. The legal certainty can be constructed through formulation of laws and regulations and clear and firm legal products so can be understood by society or the legal users. Because of that, writing about "Designing Legal Language in Strengthening the Degree of Legal Certainty" is important to do.

\section{Methodology}

This writing investigates the legal Indonesian language in the perspective of legal certainty. Analysis is begun by stating the relation of good and correct Indonesian language in the area of law with legal certainty, then followed by formulation norms of legal Indonesian language that able to create legal certainty. The writing is normative, means understanding the law from normative perspective. The used approach in this writing is statute approach, historical approach and conceptual approach.

Legal materials for analysis in the writing is primary and secondary legal materials. Primary legal materials are authoritative legal materials ${ }^{10}$. The primary legal materials in the form of Law No 8 of 1981 about Code of Criminal Procedures (KUHAP) and Constitutional Court Decision No 27/PYY-IX/2011. While the secondary materials in the research are publication about law include text books about laws and regulations, legal dictionary, legal journals, and expert comments either in the BIH areas or in the legislation drafting.

The used techniques to analyze the legal materials in the writing are (1) following the procedures of Francis Lieber, understand the legal text existence, interpret the word means as expected by the text maker, express the contained value spirit in the text, and express the conclusion based on consideration to entire text or discourse to construct precisely and correctly (2) expert test, either language or legal experts to know their comments to the legal text meaning under analysis, (3) identification, classification, and categorization of BIH formulation norms, especially form the terminoilogy, sentencing, and writing and (4) the research findings are consulted to the legal and linguistic experts so the findings can be accounted the validity.

\section{Results and discussion \\ 3.1 Legal language and legal certainty}

The term of "legal language" come from two words "language" and "legal". The both word is difficult to find precise definition that can be accepted by all parties. It does not means that both words can not be understood or explained, but still can be understood well either only in definition that given by experts in each field. The linguistic definition, according to Kridalaksana, is arbiter symbol system that used by certain society for cooperation, interact, and self identification ${ }^{11}$. While the Big Dictionary of Indonesian Language (KBBI), give language definition into three categories, that is (1) articulated vocal symbols system that is arbitrary and conventional that used as communication language produce thought and feeling (2) the used words by certain nations and (3) good conversation: good courteousness or behavior.

Related with the linguistic understanding, Bloch and Tiger stated, "“" a language is a system of arbitrary vocal symbols by means of which a social group cooperates"13. In the same vein with the argument, Broam stated "a language is a structured system of arbitrary vocal symbols by means of which members of social group interact" $"$. The definition of language, as given above, include very wide meaning and understanding. Language is not only parole, but in it contains thought, feeling, behavior, and medium to interact among human beings. In the Heidegger terms, "language is the house of beings" ". Because of that, language is vital thing for the human life and civilization.

Language vitality for human life and civilization actually has been given in al-Quran, when Allah SWT taught to Adam about names in the world so the universe can be identified easily ${ }^{16}$. Based on the facts, $\mathrm{T}$ Ramsey stated, that one of language functions is as the media to state the presence of reality or enchantment. ${ }^{17}$

The language definition has wide coverage, it can be considered from some definitions. Kridalaksana stated, language is an arbitrary vocal symbols system, that is used by societal members to cooperate, interact, and self identify. ${ }^{18}$ Keraf stated, language is communication media among societal members, in the form of vocal symbols that produced by human tongue ${ }^{19}$

Based on the both definitions above, it seems that the scope of language is very wide, so difficult to create certain definition or precise understanding. Because of that, Nababan stated, generally a language is a symbols and sign system (semiotic) that consist of signs and the relation between the elements. ${ }^{20}$ Language related closely with the conditions around the users, and language meaning related closely with the speakers, where, while, when and how. The social, professional, regional, and historical environment will influence the language and the meaning ${ }^{21}$. In the relation with the social aspects, Pateda stated that language only live because of social interaction ${ }^{22}$. Social interaction, according to Gillin is a dynamic relations, that related with among individual relationship, among human groups, or among individual and groups ${ }^{23}$. Then Soekanto proposed two requirements for social interaction occurrence, that is the presence of social contact and communication ${ }^{25}$

As for language, law also has very wide coverage. Immanual Kant, stated "Noch suchen die Juristen eine Definition zu ihrem Begriffe von recht" (up to now the legal experts are still looking for the legal definition). 
The law term come from Arabic language, Hukmun, means, determine. The meaning of law in the Arabic language equal with the legal understanding that was developed by investigation in the legal theories, legal science, and social study about law. Beside that, law is also considered as norms that qualify the certain events and facts then become event that has legal consequences. The legal concepts are usually associated with the regulation, command, prohibition, and sanction, so law in general regulate: the obligated, the prohibited, and the permitted. Friedman stated, "law is in the atmosphere, invisible an unfelt- often an light as air to the normal touch"26

Talking about legal language in Indonesia should be begun by analysis of law and Indonesian language. If viewed from the linguistic perspective, legal language become part of certain national culture in the certain societal environment. In the Indonesian context, legal language is part of national Indonesian language that is specially used in the legal area. With other words, legal language is the motif of special language usage in the legal area. That things can be observed in the legal scientific work, legislation, requisitoir, pledoi, and letters in the case; such as rejoinder, response, and conclusion.

Based on the principle that Legal Indonesian Language (BIH) is part of Indonesian language, then $\mathrm{BIH}$ should fulfill the good and correct Indonesian language rules, including system of word selection, sentence arrangement, term, structure, style, and the spelling. It means, each stipulation that prevails in Indonesian language should be obeyed by BIH. Because of that, BIH should get special from legal experts, law makers, law users, and law officer (judge, attorney, lawyer, notary, and polices). It is important to make the used BIH in the legal area either in the legislation or other legal product, not ambiguous (multi interpretation) so produce legal certainty.

Indonesian language that is used in the laws and regulations and decision in legal area still multi interpretation and not simple. It can be occurred because of two things. First, the rule maker and the law enforcers are lack of mastery for good and correct Indonesian language. Second, the rule maker and the law enforcer intentionally don not obey the language rule although they know it. Beside that, the minimum equivalent vocabularies in Indonesian make various legal document still uses foreign language, such as English and Dutc

\subsection{The importance of legal language in creating the legal certainty}

The close relation between language and law was described by S. Takdir Alisjahbana as follows ${ }^{28}$ :

“.... either language or law is the embodiment of human life in society as part of the embodiment of culture at certain time and place. In the relation of certain society and culture, language and law are interrelating, inter influencing, even the culture should be considered as the embodiment of the society and the culture, that is influenced also by language or law"

The close relation between language and law was described by Harkrisnowo as follow, "In every society, law as one of medium to create social regularity and order, is formulated mainly through language, although there are other important symbols to determine the $\operatorname{law}^{29}$. Because of that, in formulating the laws and regulation stipulations, the legislators should use the existing language rules, that is short, firm, clear, language and easy to understand by society. For example, to expand the word definition that has been known by public without making new definition, the law makers can use word "include" that will include the object definition that mentioned after. In the contrary, to narrow the definition can use word "does not include"

Observes the both statement above then connect them with the reality, it is relevant if Alisjahbana also stated "the legal strength is based on the linguistic strength" ${ }^{30}$. In similar vein with the statement, WIlhem von Humbolt stated, law get energy from language and in the law the language is the clear embodiment of energy.

The close relation between language and law has placed language as the man medium in formulating the legal norms or other legal products. Since law in the form of text, language has main role. Law become linguistic form (talig, Dutch) or language game. The legal embodiment also shifts from real world to the virtual world (read: language) that consist of sentences and words. ${ }^{32}$ Because of that, according to Rahardjo, each making the written formulation (law), then we have reduced a whole idea into certain sentence. Also, make written law does not same with moving the reality perfectly into text, so there is perfect equivalence, beside translating the facts into sentence. ${ }^{33}$

The relation between language and law not only appear when the law formulates the behavior and relationship in the societal life, but also appear when the law enforce its functions to reach and maintain the order. ${ }^{34}$ It can be observed when the language be used to guide, direct, and organize substantive idea that become the legal material contents or in the process to enforce the law in the court. In the context, language as the communication medium hold important role. Because of that, uses language in this context not only communicate, just understand, but also obey the prevailing linguistic rules ${ }^{35}$.

In the law, the role of language is not only limited at the written law, but also the emerged and maintained legal rules in the state administration, that is called as convention. ${ }^{36}$ If the law is viewed as a system, consistency principles for language rules usage does not only prevail in rules of law, but also in the relation with the other 
rule of law, including custom law. The law as the entire behavior rules that aims at reaching public order requires the presence of firmness, clarity, and preciseness, either in the word selection, term, or sentence arrangement ${ }^{37}$. So the usage of language in the legal areas should be suitable with the prevailing rules. It is important to make the law can be understood by society. If the law is understood by all society ${ }^{38}$, then its presence will create legal certainty. In the contrary, if the law can not be understood by all society, then its presence unable to create the legal certainty.

In the welcome of National Awakening Day of $87^{\text {th }}$, May 20 of 1995, President Soeharto said:

"The use of ordered language shows ordered thinking and action. The order is the basic of ordered societal, national and state life. The order is foundation for the peaceful and welfare feeling. The order is the foundation for modern and developed societies. Think orderly, have attitude orderly, and behave orderly are the essence of national disciplines"

Based on the explanation above, it can be said that the law has important element in the form of language. Law is embodied through the used language or expressed through symbols that aims at regulate and discipline the society ${ }^{39}$. Because of that, it can be said that law has very close relation with the language.

Legal language in this discussion is the language that used in the legal area, especially law in Indonesia. The meaning of legal language in here can be in the form of Indonesian language that is used in the Indonesian law area or foreign language (such as Arabic, Dutch, English, Germany, and others) that are used in the legal area but have been translated into Indonesian language, then be used in the legal area in Indonesia.

Legal Indonesian language has certain characteristic if be compared with language that is used in other legal area. The characteristic is the specialty of terms, and word selection, structure, writing composition and expression style. Legal Indonesian language aims at embodying the certainty, justice, and benefit for society. Beside embodying the justice, legal Indonesian language also to defend the public or personal interest in the society ${ }^{40}$. Because of that legal Indonesian language that is used should be clear in meaning, monosemantic, and not multi interpretation or not ambiguous. If the criteria are not fulfilled, then legal Indonesian language that will be used will be multi interpretation.

3.3 Process and Mechanism in formulating standard approach to strengthen the degree of legal certainty The findings in the writing showed that Indonesian language has been used as media in the legal area. In other parties, it seem that the investigation results need further investigation, especially if based on investigation about terminology, sentencing, and writing in the used legal Indonesian language.

Theoretically it can be stated that good and correct Indonesian language related with how to understand the writing and clarify the mind content, especially in the written language diversity. For the reader, good and correct Indonesian language serve to help the readers in understanding the writer thinking way; while for the writers, good and correct Indonesian language to explain the writer's way of thinking to make his writing easy to understand for the reader. Because of that, Indonesian language that is used in the legal areas, that is called as Legal Indonesian Language (BIH) should obey the rule and norm of good and correct Indonesian language. The disobedience causes meaning or sentence obscurity, so the words or sentences are multi interpretation. Beside that, the disobedience to the good and correct Indonesian language in drafting Legal Indonesian Language will produce meaning obscurity that will be delivered through the existing section. If the meaning is obscure, then will produce legal uncertainty. Because of that, it is relevant if Padmo Wahyono stated:

"A bachelor of law should be someone that mastering language that is used to formulate the law as the absolute requirement in the future. The "argument" expression is not excessive because a bachelor of law should able to formulate/state well by using language as media, about right and duties and other stipulation that related with the execution of the rights and duties. The activities will seem better in formulating the law and regulation or in the enforcement in the society. It will be reflected either in the term variety, term, or the sentence pattern that are used, in sum, "the legal language" 41.

The terminology analysis results in the BIH still contain weaknesses as follow. First, the limited amount and type of terms, either general or special term ${ }^{42}$. Second, there is no terminology formulation norm in the BIH that able to create legal certainty. Third, no term standardization in the legal area. Fourth, no term socialization in the legal area that is standardized. Fifth, no attitude and action uniformity of legal user to the terminology in the Legal Indonesian Language.

The limited term amount and types, either general or special term in the legal area, cause the laws and regulations get difficulty in making definition or giving meaning terminologically to the used legal terms. The fact, seemingly not only occurred in the legal scholars, law enforcer, or law practitioner realm, but also occurred outside of legal areas. Prof. Dr. Daoed Joesoef (when he was the Education and Cultural Ministry of Indonesian Republic) in his directing speech in the Indonesian Language Congress III, October 30 of 1978, stated that it is difficult to express the understanding of "think, thought, reason, reasoning, concept, conception, and idea" in English into Indonesian terms. Along with the statement above, Miean A Rivai, a famous scholar in biology also stated some of his study about Indonesian mushroom that is issued in English language because the technical 
matters about the mushroom terms not complete in Indonesian language ${ }^{43}$. Related with terminology, Miean A Rivai stated that terms have long term impact, develop terms similar with develop science. Because of that, the terminology weaknesses in Indonesian language should be handled with coaching and development ${ }^{44}$. Also the terminology weaknesses in the BIH should be overcome through coaching and development in Indonesian language.

The absence of terminology formulation norms in the BIH that able to create legal certainty, cause the laws and regulations makers use the legal terms suitable with their "taste". In some stipulation, the terminology often not consistent with the usage. Whereas, in drafting the norms should select and use the words or diction that fulfill certain requirements (1) truth, (2) accuracy, (3) preciseness, (4) prevalence, (5) harmony. ${ }^{45}$

Standard language is one of language diversity that should be mastered by them how participate in the scientific and academic worlds, including legal science. The diversity of standard language is the scholarly language that should fulfill language rules. One of aspects in it should fulfill the language rules is the term standardization in the legal area. There should be standardization, have potentials to produce incomprehension and misconception for readers (public) to the existing meaning. Based the definition, the legal term should be standardized. Definition is short explanation to the legal terms. It is usually at the explanation part of the laws and regulations.

The socialization effort for the legal terms that have been standardized contains weaknesses. Some facts or factors that support the statement can be rationalized as follow. First, many people in the academic world, especially in the Law Faculty, learn legal terms or BIH naturally. It means, they learn from the existing fact (used by other people/law experts) without thinking whether the terms has been standard and suitable with the good and correct rules. Beside that, either academics or legal practitioner give more emphasis to the language taste than the language reason. As the consequences, the term and Indonesian linguistic problems that is considered as trivial, so in facing they use arguments "the most important is know the meaning" or expression "the most important is can be understood" although the used words do not follow the language rules ${ }^{46}$. Second, the legal term in Indonesian language should compete with the foreign legal terms, especially from Dutch and English. The problems not only occurred at the terms usage level in the academic life but also in the law implementation in the society, especially in the court. The scholars and practitioners or legal experts usually have many foreign legal terms so they used them more than Indonesian terms. Because of that, sometime they feel strange with Indonesian terms. They are comfort by using the foreign legal terms to communicate the legal problems than the legal terms in Indonesian language. The emerging impression among them, by using the foreign legal terms bring more prestige compared with the legal terms in Indonesian language. Related with the matters, Anton M Moeliono ${ }^{47}$ stated that, "the market value of English language is better, but as nation that love its own culture, we should give priority to our own language, not underestimate it". Third, in education world (especially higher education of law) most good and complete references in foreign language, especially English language. While the student ability in the English language, average in Indonesia, not sufficient to absorb and understand the knowledge in the books. Fourth, in the academic realms or law practitioner, because they feel able to use Indonesian language they do not feel the importance to learn Indonesian language. Beside that, they give less attention to the socialization of legal terms in Indonesian language. As the consequences, the legal user society still feel strange to the foreign legal terms.

From the analysis of sentences also contain weaknesses as follow. First, the sentence mistake as the equivocal consequences. Second, the sentence mistake as the ineffectiveness consequences. Below is given some of the weaknesses. The equivocal require the legislation language without multi interpretation. The language effectiveness of legislation language can be fulfilled if the essence of effective sentence was understood uniformly. The effective sentence is sentence that make the delivered content is completely described to the reader or the received message by the reader is equal with the writer expectation. The characteristic of effective sentence (1) focus (2) parsimony (3) whole (4) relevant, and (5) parallel ${ }^{48}$

Focus is signalizing that something important given at beginning not at the end. The parsimony related with the word selection, especially synonymous should not emerge together. The wholeness require each word in sentence is part of integral (whole, compact, or united) or one unity, while the relevancy (cohesion) require one and other elements make harmonious relation, that is logical and clear for the reader. While, the parallel related with the form parallel (especially in using affix) and structural parallel (especially in the equivalent compound sentence).

Sentence arrangement effectiveness in BIH has important role in clarifying the information understanding that will be delivered. Because of that, ineffective sentence, beside unable be understand precisely, also cause misunderstanding ${ }^{49}$. In contrary, the effective sentence able to facilitate the information understanding in the text, especially sentence in the legislation and judge decision.

As in the terminology and sentence analysis, the writing analysis results also contains weaknesses. The writing problems including capital letter, punctuation mark, italic and the use of commas. But, the causes of conflict with linguist is the use of capital, coma, and double point. 
Based on explanation above, it can be concluded about the relation on good and correct Indonesian language with the legal certainty. Good and correct Indonesian language in legal area has relation with legal certainty. It is reflected in the terminology, sentencing, and writing in the legal area. The terminology, sentencing, and writing that are suitable with the good and correct Indonesian language rules will facilitate the user to understand the meaning or idea in the sentences. In the contrary, the terminology, sentencing, and writing that is not suitable with good and correct Indonesian language will bring difficulty for the legal user to understand the meaning in the legal sentences. Consequences of ambiguous terminology, the reader will try to find suitable term according to their interpretation so the obtained meaning become different. The fact showed that the objective of terminology can not be understood clearly by legal user. The consequences are able to produce legal uncertainty.

Beside the arranged terminology by following the correct rule, the simple, grammatical and effective sentence, and writing that suitable with the good and correct Indonesian language, there is convention in the legal area, such as the form and style of writing in the legal areas, that influence the legal certainty. The combination of both in arranging legal sentences, such as in the Code of Criminal Procedures and Decision of Constitutional Court, able to create legal certainty. Beside that, in the perspective of legal certainty, the good and correct Indonesian language rule and convention in the legal area can be used as guidance in the BIH that able to create legal certainty. Based on the finding, it can be concluded that legal Indonesian language able to create legal certainty that has its own model or prototype that is called as legal language harmony. The finding can be used to reveal theoretical concept that Indonesian language that is used in the legal area, that is called as Legal Indonesian Language $(\mathrm{BIH})$ is legal language harmony that has certain character.

While the norm of BIH formulation that able to create legal certainty can be described as follows. The formulation norms generally are grouped into three section, formulation norms of terminology, sentencing, and writing. Based on explanation about terminology can be revealed some formulation forms that able to create legal certainty. First, the used terminology in the definition, either nominal or formal definition is not ambiguous or conflict in the concept, process, situation or characteristic in the legal area. Second, the placement of term in the sentence considers the truth, accuracy, preciseness, prevalence, and harmony so the presence is functional in revealing the meaning of concept, process, situation or special character in legal area. Third, the terms relevance with other terms so the meaning of concept, process, situation or special character are defined in the clear systematic.

Related with the sentencing, it can be revealed some formulation norms that able to create the legal certainty. First, sentencing that has form parallelism in expressing idea or concept. The sentencing that has form parallelism using the similar sentence elements in the serial arrangement. Second, sentencing that has preciseness in placing the sentence functions (such as subject, verb, object, description or complement, abbreviated by SPOKP). A good sentence beside contains complete elements also has preciseness in placing the sentence functions. Third, sentencing that has thought unity, either core sentence or wide sentence so to be effective sentence it should reveal main idea or one thought unity. In this case, can be formed through harmony between subject-verb, verb-object, and predicate-description. Fourth, logical sentencing. Either words or terms that are used in the sentencing show logical meaning relationship. In this case, the delivered idea is reasonable and can be accepted. Related with the writing, it can be revealed some formulation norms that able to create legal certainty. First, preciseness in writing the letter, either capital or italic. Second, constancy in using punctuation marks.

\section{Conclusion}

Based on explanation above, it can be concluded that the good and correct Indonesian language in the legal areas has relation with the legal certainty. It is reflected in the terminology, sentencing, and writing that are used in the legal area. While the legal Indonesian language formulation norms that able to create legal certainty as follows. First, the terminology is not ambiguous, correct placement in sentence, and term relevance with other terms is described in clear systematic. Second, the sentencing has form parallelism, preciseness in placing the sentence functions, thought unity, and logic. Third, the preciseness in writing the letter, either capital or italic and constancy in using the punctuation marks.

\section{References}

Bahder Johan Nasution dan Sri Warjiyati. Bahasa Indonesia Hukum. Bandung: Citra Aditya Bakti, 1998. Brown, Gillian \& George Yule. Discourse Analysis. Cambridge: Cambridge UNIversity Press, 1983.

Dendy Sugono. "Bahasa Hukum", dalam Analisis dan Evaluasi tentang Perkembangan 25 Tahun Penggunaan

Bahasa Hukum. Jakarta: Badan Pembinaan Hukum Nasional, Departemen Kehakiman, 1995. . Berbahasa Indonesia dengan Benar. Jakarta: Puspa Swara, 1997.

----.-. Mahir Berbahasa Indonesia dengan Benar. Jakarta: Gramedia Pustaka Utama, 2009.

Departemen Pendidikan dan Kebudayaan. Kamus Besar Bahasa Indonesia. Jakarta: Balai Pustaka, 1994. 
Garvin, Paul dan Madeline Mathiot. “The Urbanization of The Guarani Language”. 1968.

Harimurti Kridalaksana. Pembentukan Kata dalam Bahasa Indonesia. Jakarta: PT. Gramedia, 1989.

H.A.S. Natabaya. "Bahasa Indonesia dalam Wacana Hukum" dalam Bahasa Indonesia Dalam Era Globalisasi:

Pemantapan Peran Bahasa Sebagai Sarana Pembangunan Bangsa. Jakarta: Pusat Pembinaan dan Pengembangan Bahasa, Depdiknas, 2000.

Hilman Kadikusuma. Bahasa Hukum Indonesia. Bandung: Alumni, 2008.

J.J. H. Bruggink. Refleksi tentang Hukum (Alih bahasa; Arief Sidharta). Bandung: Citra Aditya Bakti, 1999.

Komaruddin Hidayat. Memahami Bahasa Agama Sebuah Kajian Hermeneutik. Jakarta : Paramadina, 1996.

Mahadi dan Sabaruddin Ahmad. Pembinaan Bahasa Hukum Indonesia. Jakarta : Binacipta, 1983.

Masnur Muslich dan I Gusti Ngurah Oka. Perencanaan Bahasa pada Era Globalisasi. Jakarta: Bumi Aksara, 2010.

Padmo Wahyono. "Beberapa Permasalahan Bahasa Hukum Indonesia”, dalam Hukum dan Pembangunan, (No. 3 Tahun XII, Mei 1983).

Peter Mahmud Marzuki. Penelitian Hukum. Jakarta: Prenada Media Group, 2006. . Pengantar Ilmu Hukum. Jakrta: Kencana Prenada Nedia Group, 2009.

P.W.J. Nababan. "Sosiolinguistik Selayang Pandang" dalam Pengajaran Bahasa dan Sastra Tahun V Nomor 1 Hlm. 7-21. Jakarta: Pusat Pembinaan dan Pengembangan Bahasa, 1979.

Riris K. Toha Sarumpaet. Anton M. Moeliono dengan Bahasa Membangun Bangsa. Jakarta: UI-Press, 2011.

Satjipto Rahardjo. Penegakan Hukum Progresif. Jakarta: Kompas, 2010.

Shidarta. Karakteristik Penalaran Hukum dalam Konteks Keindonesiaan. Bandung: CV. Utomo, 2009.

Soedjito dan Djoko Saryono. Kosakata Bahasa Indonesia. Malang: Aditya Media Publishing, 2011.

Soelaeman B. Adiwidjaya dan Lilis Hartini. Bahasa Indonesia Hukum. Bandung: Pustaka, 2002.

Soerjono Soekanto. Sosiologi Suatu Pengantar. Jakarta : Rajawali, 2000.

S.S.T. Wisnu Sasangka. Bahasa Indonesia dalam Perundang-undangan. Jakarta: Pusat Bahasa, tanpa Tahun. S. Takdir Alisjahbana. Dari Perjuangan dan Pertumbuhan Bahasa Indonesia. Jakarta: Pustaka Rakyat, 1957.

"Bahasa Hukum Beberapa Sumbangan Pikiran Menuju Ke Arah Pembentukan dan Pemakaian Bahasa yang Baik”, dalam Simposium Bahasa dan Hukum. Jakarta: Binacipta, 1974.

Sudikno Mertokusumo. Mengenal Hukum Suatu Pengantar. Yogyakarta: Universitas Atma Jaya, 2010. 